AKUNSIKA: Jurnal Akuntansi dan Keuangan

Volume 1 Nomor 1, Januari 2020

http://jurnal.poliupg.ac.id/index.php/akunsika

\title{
Pengaruh Regret Aversion Bias dan Risk Tolerance Bagi Investor Muda Jawa Barat terhadap Keputusan Investasi
}

\author{
Wahyu Nurdinda \\ Universitas Singaperbangsa Karawang \\ wahyunurdinda@gmail.co \\ Asep Muslihat \\ Universitas Singaperbangsa Karawang \\ asep_muslih@yahoo.co \\ Raden Aditya Kristamtomo Putra \\ Universitas Singaperbangsa Karawang \\ radityakp.unsika@gmail.co
}

(Diterima: 19-Desember-2019; dipublikasikan: 31-Januari-2020)

\begin{abstract}
This study aims to describe the influence of regret aversion bias and risk tolerance on west java young investors through investment decision partially and simultaneously. Data obtained by distributing questionnaires in 8 State Universities in West Java with sample of 363 people taken from grade 2015 of Economics and Business Faculty students. After the data is obtained, then the data is analyzed using the path analysis. The results of the verification test showed regret aversion bias partially has total influence $7 \%$ on investment decision while risk tolerance partially has total influence $22,8 \%$ on investment decision, finally total influence of regret aversion bias and risk tolerance on investment decision simultaneously is equal $29,8 \%$ and the influence of other variables outside the model is $70.2 \%$.
\end{abstract}

Keywords: Regret aversion bias; Risk tolerance; Investment Decision; Young Investors

\begin{abstract}
Abstrak
Penelitian ini bertujuan untuk menggambarkan pengaruh parsial dan simultan variabel regret aversion bias dan risk tolerance pada investor muda Jawa Barat terhadap keputusan investasi. Data didapatkan dengan menyebar kuesioner di 8 Perguruan Tinggi Negeri di Jawa Barat dengan jumlah sampel 363 orang yang diambil dari mahasiswa Fakultas Ekonomi dan Bisnis angkatan 2015. Data yang telah diperoleh selanjutnya dianalisis menggunakan metode analisis jalur. Adapun hasil secara parsial menunjukkan variabel regret aversion bias mepunyai total pengaruh sebesar $7 \%$ terhadap keputusan investasi sedangkan variabel risk tolerance mempunyai total pengaruh sebesar $22,8 \%$ sehingga total pengaruh secara simultan variabel regret aversion bias dan risk tolerance terhadap keputusan investasi sebesar 29,8\% adapun pengaruh dari variabel lain di luar model sebesar 70,2\%. Sehingga dapat diketahui bahwa variabel risk tolerance menjadi pengaruh utama pada investor muda Jawa Barat untuk melakukan investasi..
\end{abstract}

Kata Kunci: Regret aversion bias; Risk tolerance; Keputusan Investasi; Investor Muda 


\section{PENDAHULUAN}

Kinerson dan Bailey (2005) mengatakan bahwa manusia telah melakukan investasi sejak beratus-beratus tahun yang lalu. Dengan melakukan investasi mereka berharap akan mendapatkan keuntungan di masa yang akan datang. Dalam pengambilan keputusan investasi, manusia dihadapkan pada beberapa risiko investasi yang mengakibatkan proses memilih investasi menjadi tidak mudah karena akan menimbulkan konsekuensi keuangan yaitu untung atau rugi. Dianggap sulit karea risiko investasi merupakan suatu ketidakpastian (speculative risk) yang mengakibatkan diperolehnya keuntungan atau kerugian sesuai gambar 1 .

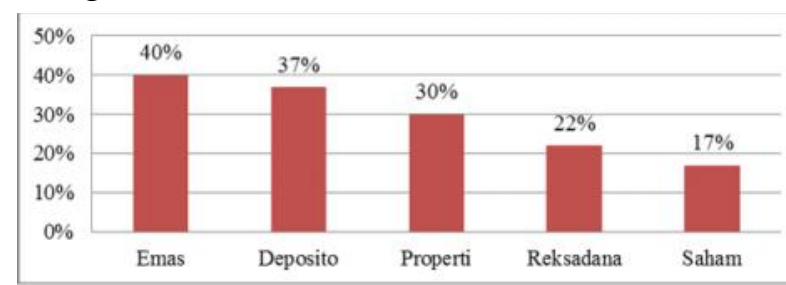

Gambar 1 Penelitian yang Umum di Indonesia

Dari gambar diketahui bahwa orang $40 \%$ Indonesia sangat gemar berinvestasi di emas dan $17 \%$ investasi di saham. Hal ini dapat disimpulan bahwa setiap investasi memiliki risiko yang berbeda sesuai dengan hasil yang akan didapat karena semakin tinggi keuntungan suatu investasi semakin tinggi risikonya pula. Dilihat dari kelompok usia, orang Indonesia yang berusia 31-35 tahun dan 41-45 tahun cenderung lebih aktif berinvestasi. Adapun, usia 20 tahun ke bawah 46 tahun ke atas adalah kelompok usia dengan angka partisipasi terendah untuk berinvestasi (www.idntimes.com, 2018).

Apabila dilihat dari tingkat pengembalian (return) dalam jangka waktu sepuluh tahun terakhir, IHSG atau investasi saham meperoleh $327.71 \%$ dan hasil pengemblian (return) yang paling kecil adalah menabung di bank memperoleh $14.34 \%$. Oleh karena itu investasi saham cukup menjanjikan yang menyebabkan banyak yang tertarik untuk melakukannya.
Sayangnya, kebanyakan orang awam yang melakukan investasi saham hanya sebatas ikut-ikutan dan tidak melakukan analisis investasi saham secara komprehensif (www.kresnasecurities.com, 2017).

Menurut Markowitz (1952) proses memilih sebuah portofolio mempunyai dua tahapan. Tahap pertama adalah pembentukan belief akan sebuah aset meliputi kinerja masa yang akan datang dari observasi dan pengalaman. Setelah belief terbentuk, tahap selanjutnya adalah menentukan pilihan portofolio. Setiap orang pasti mengharapkan pilihan yang dibuat memberikan keuntungan. Secara rasional, belief akan portofolio tersebut adalah mengharapkan keuntungan (expected return atau anticipated return) yang lebih besar dari keuntungan yang sudah pasti dapat diperoleh. Tapi pada kenyataannya investor sering bersikap irrasional. Hal ini tak lepas dari perkembangan investasi di Indonesia sangat pesat khususnya pada investasi saham. Investasi saham sangat menjanjikan dengan tingginya keuntungan yang akan didapat menyebabkan banyak masyarakat yang tertarik untuk masuk ke dunia investasi saham. Akan tetapi, orang awam yang melakukan investasi hanya sebatas ikutikutan tanpa memperhatikan risiko dari investasi tersebut.

Pendekatan ilmu manajemen keuangan yang mempelajari tentang perilaku investor dalam mengambil keputusan adalah behavioral finance. Selain ilmu ekonomi khususnya manajemen keuangan, behavioral finance juga melibatkan ilmu psikologi. Faktor psikologis seorang investor sangat berpengaruh terhadap keputusan investasinya. Menurut Shefrin (2005) behavioral finance merupakan ilmu bagaimana fenomena psikologi mempengaruhi perilaku keuangan. Sedangkan menurut Olsen (1998), behavioral finance berusaha mengungkap pengertian dan prediksi pasar keuangan yang berfokus pada penerapan prinsip psikologi dan ekonomi sebagai pengembangan proses pengambilan keputusan keuangan. Selain itu, penelitian Kahneman dan Tversky 
(2000) menjelaskan tentang prospect theory yang berkaitan dengan ide bahwa manusia tidak selalu berperilaku secara raisonal. Keterlibatan emosi, kesukaan, sifat dan berbagai macam hal yang melekat di dalam diri manusia sering menyebabkan manusia tidak selalu berperilaku rasional dalam mengambil sebuah keputusan. Teori ini beranggapan bahwa ada bias yang melekat dan pengaruh faktor-faktor psikologis yang mempengaruhi pilihan seseorang pada kondisi ketidakpastian.

Pompian (2006) dalam Yohnson (2008) membagi bias menjadi 2 kategori. Pertama, cognitive bias contohnya overconfidence bias. Kedua, emotional bias contohnya loss averstatus quo bsion bias, regret aversion bias dan ias. Menurut Yohnson (2008) regret aversion bias merupakan suatu penyesalan yang timbul akibat mengalami kerugian sehingga adanya keputusan untuk menghindari kesalahan yang sama. Regret aversion bias menyebabkan investor menjadi terlalu konservatif, terlalu antipati terhadap pasar karena pasar terus turun, investor pada posisi rugi yang cukup lama, muncul herding behavior (sikap ikut-ikutan) pada investor (Pompian, 2006 dalam Yohnson, 2008). Dalam penelitian yang dilakukan oleh Kinerson dan Bailey (2005) dan Yohnson (2008), variabel regret aversion bias dibagi menjadi dua yaitu experienced regret dan anticipated regret. Experienced regret didasarkan pada penelitian Loomes dan Sudgen (1982). Sedangkan anticipated regret didasarkan pada penelitian Bell (1982). Pada penelitian sebelumnya, hasil dari penelitian yang dilakukan oleh Kinnerson dan Bailey (2005), Loomies dan Sudgen (1982) adalah experienced regret berpengaruh signifikan terhadap keputusan investasi. Menurut hasil penelitian Bell (1982) serta Wong dan Kwong (2007) bahwa anticipated regret berpengaruh signifikan terhadap keputusan investasi. Secara keseluruhan, regret aversion bias mempengaruhi keputusan investasi. Namun, masing-masing komponen dari regret aversion bias (experienced regret atau anticipated regret) memiliki perbedaan pengaruh terhadap keputusan investasi.

Selain faktor regret aversion bias, keputusan investasi juga dipengaruhi oleh faktor risk tolerance. Droms (1987) menemukan bahwa risk tolerance merupakan salah satu faktor penentu pemilihan sebuah portfolio yang optimal berdasarkan kebutuhan setiap individu dalam memandang risk dan return. Penelitian sebelumnya yang dilakukan oleh Droms (1987), Kinerson dan Bailey (2005) dan Yohnson (2008) ditemukan bahwa variabel risk tolerance berpengaruh signifikan terhadap keputusan investasi. Dapat disimpulkan bahwa risk tolerance secara keseluruhan mempengaruhi keputusan investasi, namun masing-masing level dari risk tolerance (tinggi atau rendah) memiliki perbedaan pengaruh terhadap keputusan investasi hal ini disebabkan setiap individu memiliki pendekatan yang berbeda dalam pemilihan sebuah portofolio setelah melakukan analisis baik fundamental ataupun technical sebelum pengambilan keputusan.

Berdasarkan latar belakang yang telah diuraikan sebelumnya, tujuan dari penelitian ini adalah sebagai berikut: Mengetahui pengaruh Regret aversion bias dan Risk tolerance bagi investor muda jawa barat terhadap keputusan investasi secara parsial dan simul$\tan$.

\section{METODE PENELITIAN}

\section{Populasi dan Sampel}

Populasi dari penelitian ini adalah mahasiswa S1 dan Diploma Fakultas Ekonomi dan Bisnis Angkatan 2015 di 8 Peguruan Tinggi Negeri yang memiliki Galeri Investasi dengan hubungan tripartit di Jawa Barat yaitu: Universitas Padjadjaran (Bandung), Universitas Indonesia (Depok), Universitas Siliwangi (Tasikmalaya), Universitas Singaperbangsa Karawang (Karawang), Institut Pertanian Bogor (Bogor), Institut Teknologi Bandung (Bandung), Politeknik Negeri Bandung (Bandung), dan IAIN Syekh Nurjati (Cirebon) dengan total populasi sebesar 3.897 . 
Adapun sampel dengan menggunakan rumus slovin dengan standar error 5\% maka didapat total sampel sebanyak 363 dan dengan menggunakan teknik sampling Proportionate Stratified Random Sampling maka didapatlah besaran proporsional di 8 kampus yaitu: Universitas Padjadjaran (Bandung) sebanyak 39 mahasiswa, Universitas Indonesia (Depok) sebanyak 102 mahasiswa, Universitas Siliwangi (Tasikmalaya) sebanyak 31 mahasiswa, Universitas Singaperbangsa Karawang (Karawang) sebanyak 37 mahasiswa, Institut Pertanian Bogor (Bogor) sebanyak 45 mahasiswa, Institut Teknologi Bandung (Bandung) sebanyak 60 mahasiswa, Politeknik Negeri Bandung (Bandung) sebanyak 25 mahasiswa, dan UIN Syekh Nurjati (Cirebon) sebanyak 24 mahasiswa.

\section{Teknik Pengumpulan Data}

Sumber data yang digunakan oleh penelitian ini adalah data primer dari kuesioner yang disebar di 8 PTN di Jawa Barat dengan skala likert, yaitu untuk mengukur variabel penelitian. Variabel yang diukur dijabarkan menjadi indikator variabel. Indikator variabel tersebut dijadikan tolak ukur untuk menyusun item-item instrumen, dapat berupa pernyataan atau pertanyaan. Jawaban setiap instrumen mempunyai gradasi sangat positif sampai sangat negatif.

\section{Metode Analisis}

Teknik analisis data yang digunakan dalam penelitian ini adalah analisis jalur dengan bantuan program SPSS versi 22 . Dengan metode ini dapat diketahui besaran pengaruh variabel bebas terhadap variabel terikat. Adapun model yang digunakan yakni

$$
Y=\rho \mathrm{yx}_{1} X_{1}+\rho \mathrm{yx}_{2} \mathrm{X}_{2}+\varepsilon
$$

Keterangan :

$\mathrm{X}_{1}$ : regret aversion bias

$\mathrm{X}_{2}$ : risk tolerance

$\mathrm{Y}$ : keputusan investasi

$\varepsilon$ : Faktor lain yang tidak diteliti

pyx ${ }_{1}$ : Koefisien jalur yang menggambarkan

besarnya pengaruh $\mathrm{X}_{1}$ terhadap $\mathrm{Y}$ $\rho \mathrm{yx}_{2}$ : Koefisien jalur yang menggambarkan besarnya pengaruh $\mathrm{X}_{2}$ terhadap $\mathrm{Y}$

$\mathrm{rx}_{1} \mathrm{X}_{2}$ : Korelasi $\mathrm{X}_{1}$ dan $\mathrm{X}_{2}$

\section{Variabel Operasional}

Variabel Operasional dalam penelitian ini terdiri dari variabel dependen dan variabel independen.

1. Variabel dependen : Keputusan Investasi

2. Variabel independen : regret aversion bias dan risk tolerance.

\section{HASIL DAN PEMBAHASAN}

\section{Karakteristik Responden}

Untuk mengetahui karakteristik responden penelitian ini tersaji pada tabel 1 .

\section{Uji Validitas}

Seluruh indikator keputusan investasi valid karena nilai seluruh indikator lebih dari r Tabel yaitu 0,1217. Menurut Sujarweni (2016:247) uji validitas dapat diketahui dengan membandingkan $r$ Hitung dan $r$ Tabel dengan sig 5\%. Apabila $\mathrm{r}$ Tabel $<\mathrm{r}$ Hitung maka dinyatakan valid. Hasil $r$ Tabel < $r$ Hitung maka dinyatakan valid secara lengkap tersaji pada tabel 2.

\section{Uji Reliabilitas}

Hasil Cronbach's Alpha seperti tabel 3 sebesar 0,833. Artinya nilai Cronbach's Alpha sebesar $0,833>0,6$, maka kuesioner dinyatakan reliabel atau konsisten. Menurut Sujarweni (2016:247) jika nilai Cronbach's Alpha > 0,6 maka kuesioner dinyatakan reliable dan jika nilai Cronbach's Alpha $<0,6$ maka kuesioner dinyatakan tidak reliabel.

\section{Pengujian Hipotesis}

\section{Pengaruh Regret Aversion Bias Terhadap Keputusan Investasi}

Pengujian hipotesis pengaruh parsial variabel regret aversion bias terhadap keputusan investasi dapat dilihat pada tabel 4 . Dari tabel 4 diketahui t hitung $(2,834)>\mathrm{t}$ tabel $(2,3367)$ maka $H_{o}$ ditolak. Dengan demikian dapat disimpulkan bahwa regret aversion bias secara parsial berpengaruh terhadap keputusan investasi. Hal ini diperkuat 
dari hasil penelitian Kinnerson dan Bailey (2005), Loomies dan Sudgen (1982), Putra et al (2016), Bell (1982), serta Wong dan Kwong (2007) bahwa experienced regret dan anticipated regret berpengaruh signifikan terhadap keputusan investasi. Menurut Menurut Yohnson (2008) ada 4 faktor (diambil dari 10 karakteristik unik konsumen Indonesia) yang mempengaruhi regret aversion bias bukan merupakan pengaruh utama antara lain: pertama, konsumen Indonesia memiliki memori jangka pendek berarti diduga investor Indonesia ingin menghasilkan return tinggi jangka pendek sehingga regret diabaikan. Kedua, konsumen Indonesia suka kumpul bersama koleganya berarti keputusan investasi juga dipengaruhi oleh koleganya yang sangat yakin dengan pendapatnya sehingga regret bisa diabaikan. Ketiga, konsumen Indonesia sangat religius, berarti dalam investasi penuh pengharapan baru sehingga regret diabaikan (mahasiswa yang menjadi responden berasal dari universitas yang menekankan pendidikan dengan nilai-nilai kebenaran). Keempat, konsumen Indonesia suka pamer dan gengsi, berarti berdampak pada perilaku investasi yang hanya berdasarkan gengsi sehingga regret bisa diabaikan.

\section{Pengaruh Risk Tolerance Terhadap Keputusan Investasi}

Pengujian hipotesis pengaruh parsial variabel risk tolerance terhadap keputusan investasi dapat dilihat pada tabel 5. Dari tabel 5 diketahui t hitung $(7,542)>\mathrm{t}$ tabel $(2,3367)$ maka $\mathrm{H}_{\mathrm{o}}$ ditolak. Dengan demikian dapat disimpulkan bahwa Risk Tolerance secara parsial berpengaruh terhadap Keputusan Investasi. Hal ini diperkuat dari hasil penelitian Kinerson dan Bailey (2005), Yohnson (2008), dan Putra et al (2016) ditemukan bahwa variabel risk tolerance berpengaruh signifikan terhadap keputusan investasi.

\section{Pengaruh Regret Aversion Bias dan Risk Tolerance Terhadap Keputusan Investasi}

Pengujian hipotesis pengaruh parsial variabel regret aversion bias dan risk tolerance terhadap keputusan investasi dapat dili- hat pada tabel 6. Dari tabel 6 dapat diketahui f hitung $(76,379)>\mathrm{f}$ tabel $(1,197)$ maka $\mathrm{H}_{\mathrm{o}}$ ditolak. Dengan demikian dapat disimpulkan bahwa regret aversion bias dan risk tolerance berpengaruh secara simultan terhadap keputusan investasi. Hal ini diperkuat oleh hasil penelitian Budiarto \& Susanti (2017) bahwa variabel regret aversion bias berpengaruh terhadap keputusan investasi investor sehingga hal ini menunjukkan jika investor mengalami suatu kegagalan atau kerugian dalam pilihannya akan membuat efek trauma terhadap keputusan investasi yang akan datang. Sedangkan menurut Budiarto \& Susanti (2017) variabel risk tolerance berpengaruh terhadap keputusan investasi investor. Dalam penelitian itu juga membuktikan bahwa pelaku investasi berisiko tinggi memiliki tingkat risk tolerance yang tinggi. Para investor muda beranggapan bahwa faktor gain menjadi salah satu motivasi mereka untuk memilih investasi khususnya di saham. Sedangkan responden yang memiliki risk tolerance rendah akan cenderung memilih investasi yang berisiko rendah contohnya deposito. Faktor rasa aman menjadi salah satu alasan mereka untuk memilih investasi walaupun keuntungan yang didapat tidak terlalu besar (Wulandari dan Iramani, 2014:58).

Dari tabel 7 menunjukan bahwa koefisien determinasi $\left(\mathrm{R}^{2}\right)$ sebesar 0,298 berarti $29,8 \%$ variabel keputusan investasi dapat diterangkan oleh regret aversion bias dan risk tolerance. Sedangkan sisanya $100 \%$ $29,8 \%=70,2 \%$ merupakan kontribusi variabel lain ( ) yang tidak diteliti dalam penelitian ini.

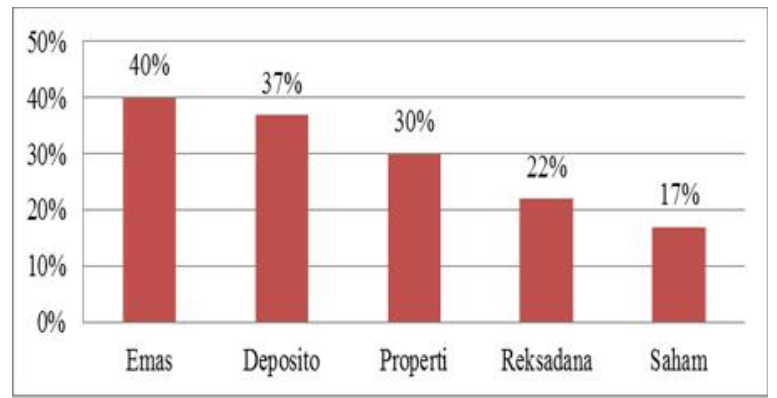

Gambar 1 Investasi Yang Umum di Indonesia 
Tabel 1 Karakteristik Responden

\begin{tabular}{|c|c|c|c|}
\hline No & Responden & Jumlah (Orang) & Persentase $(\%)$ \\
\hline \multicolumn{4}{|c|}{ Berdasarkan Kelamin } \\
\hline 1 & Laki-laki & 230 & $63 \%$ \\
\hline 2 & Perempuan & 133 & $37 \%$ \\
\hline \multicolumn{2}{|r|}{ Jumlah } & 363 & $100 \%$ \\
\hline \multicolumn{4}{|c|}{ Berdasarkan Umur } \\
\hline 1 & 17 - 22 Tahun & 261 & $72 \%$ \\
\hline 2 & 22 - 27 Tahun & 86 & $24 \%$ \\
\hline 3 & 27 - 32 Tahun & 16 & $4 \%$ \\
\hline 4 & > 32 Tahun & 0 & $0 \%$ \\
\hline \multicolumn{2}{|r|}{ Jumlah } & 363 & $100 \%$ \\
\hline \multicolumn{4}{|c|}{ Berdasarkan Pendapatan } \\
\hline 1 & $<$ Rp1.000.000 & 78 & $21 \%$ \\
\hline 2 & Rp1.000.001 - Rp3.000.000 & 194 & $53 \%$ \\
\hline 3 & Rp3.000.001 - Rp5.000.000 & 79 & $22 \%$ \\
\hline 4 & $>$ Rp5.000.000 & 12 & $3 \%$ \\
\hline & Jumlah & 363 & $100 \%$ \\
\hline & \multicolumn{3}{|c|}{ Berdasarkan Kepemilikan Investasi } \\
\hline 1 & Memiliki & 169 & $47 \%$ \\
\hline 2 & Tidak Memiliki & 194 & $53 \%$ \\
\hline & Jumlah & 363 & $100 \%$ \\
\hline
\end{tabular}

Sumber : Hasil Kuesioner Peneliti, 2019

Tabel 2 Hasil Uji Validitas

\begin{tabular}{|c|c|c|c|c|}
\hline \multicolumn{5}{|c|}{ Indikator Variabel Regret Aversion Bias } \\
\hline 1 & Pengalaman Merugi Membuat Takut Berinvestasi & 0,509 & 0,1217 & Valid \\
\hline 2 & Pengalaman Tertipu Membuat Takut Berinvestasi & 0,424 & 0,1217 & Valid \\
\hline 3 & Keuangan Tertanggu Setelah Berinvestasi & 0,395 & 0,1217 & Valid \\
\hline 4 & Pengalaman Buruk Membuat Berinvestasi & 0,356 & 0,1217 & Valid \\
\hline 5 & $\begin{array}{l}\text { Penyesalan Setelah Salah Membuat Keputusan Invetasi } \\
\text { Membuat Tidak Berani Melakukan Investasi Kembali }\end{array}$ & 0,415 & 0,1217 & Valid \\
\hline 6 & $\begin{array}{l}\text { Pengalaman Meneysal itu Membuat Berhati-hati Ketika } \\
\text { Berinvestasi Kembali }\end{array}$ & 0,497 & 0,1217 & Valid \\
\hline \multicolumn{5}{|c|}{ Indikator Variabel Risk Tolerance } \\
\hline 1 & Investasi Berisiko Tinggi Prioritas Saya & 0,333 & 0,1217 & Valid \\
\hline 2 & $\begin{array}{l}\text { Investasi Berisiko Tinggi Memberikan Return Tinggi } \\
\text { Pula }\end{array}$ & 0,397 & 0,1217 & Valid \\
\hline 3 & Memilih Investasi Dengan Risiko Masuk Akal & 0,459 & 0,1217 & Valid \\
\hline 4 & Menjadi Investor Netral Membuat Hidup Tenang & 0,458 & 0,1217 & Valid \\
\hline 5 & Investasi Berisiko Rendah Prioritas Saya & 0,310 & 0,1217 & Valid \\
\hline 6 & Investasi Risiko Rendah Membuat Hidup Tenang & 0,443 & 0,1217 & Valid \\
\hline \multicolumn{5}{|c|}{ Indikator Variabel Keputusan Investasi } \\
\hline 1 & $\begin{array}{l}\text { Menjadi Sejahtera Di Kemudian Hari Adalah Tujuan Ber- } \\
\text { investasi }\end{array}$ & 0,552 & 0,1217 & Valid \\
\hline 2 & Konsisten Mengeluarkan Uang Untuk Berinvestasi & 0,551 & 0,1217 & Valid \\
\hline 3 & Promosi Investasi Di Media Membuat Tertarik & 0,399 & 0,1217 & Valid \\
\hline 4 & $\begin{array}{l}\text { Kerelaan Mengeluarkan Uang Untuk Investasi Jangka } \\
\text { Panjang }\end{array}$ & 0,397 & 0,1217 & Valid \\
\hline 5 & $\begin{array}{l}\text { Kerelaan Mengeluarkan Uang Untuk Investasi Jangka } \\
\text { Pendek }\end{array}$ & 0,353 & 0,1217 & Valid \\
\hline 6 & Mengupdate Informasi Seputar Dunia Investasi & 0,360 & 0,1217 & Valid \\
\hline
\end{tabular}

Sumber : Hasil Perhitungan SPSS, 2019 
Wahyu Nurdinda, Pengaruh Regret Aversion Bias dan Risk Tolerance ... 36

Tabel 3. Hasil Uji Reliabilitas

\begin{tabular}{rrr}
\multicolumn{2}{c}{ Reliability Statistics } & \\
\hline Cronbach's Alpha & N of Items \\
\hline & .833 & 18 \\
\hline
\end{tabular}

Sumber : Hasil Perhitungan SPSS, 2019

Tabel 4. Uji t Variabel $X_{1}$

\begin{tabular}{cccccc}
\hline Struktural & Sig. & $\alpha$ & t hitung & t tabel & Kesimpulan \\
\hline pyx $_{1}$ & 0.005 & 0,05 & 2,834 & 2,3367 & $\mathrm{H}_{\mathrm{o}}$ ditolak \\
\hline
\end{tabular}

Sumber : Hasil Perhitungan SPSS, 2019

Tabel 5. Uji t Variabel $X_{2}$

\begin{tabular}{cccccc}
\hline Struktural & Sig. & $\alpha$ & t hitung & t tabel & Kesimpulan \\
\hline $\operatorname{pyx}_{2}$ & 0.000 & 0,05 & 7,542 & 2,3367 & $\mathrm{H}_{\mathrm{o}}$ ditolak \\
\hline
\end{tabular}

Sumber : Hasil Perhitungan SPSS, 2019

Tabel 6. Uji F Variabel $X_{1}$ dan $X_{2}$ terhadap $Y$

\begin{tabular}{cccccc}
\hline Struktural & Sig. & $\alpha$ & f hitung & f tabel & Kesimpulan \\
\hline $\operatorname{pyx}_{1} \mathrm{x}_{2}$ & 0.000 & 0,05 & 76,379 & 1,197 & $\mathrm{H}_{\mathrm{o}}$ ditolak \\
\hline
\end{tabular}

Sumber : Hasil

Perhitungan

SPSS, 2019

Tabel 7. $R$

Square

Model Summary

\begin{tabular}{ccccc}
\hline Model & $\mathrm{R}$ & R Square & $\begin{array}{c}\text { Adjusted R } \\
\text { Square }\end{array}$ & $\begin{array}{c}\text { Std. Error of the } \\
\text { Estimate }\end{array}$ \\
\hline 1 & $.546^{\mathrm{a}}$ & .298 & .294 & 3.3731707 \\
\hline
\end{tabular}

a. Predictors:

(Constant), Risk

Tolerance, Regret

Aversion Bias

b. Dependent Vari-

able: Keputusan

Investasi

Sumber : Hasil Perhitungan SPSS, 2019 


\section{KESIMPULAN}

Berdasarkan hasil penelitian dan pembahasan yang telah dijelaskan sebelumnya, maka kesimpulan dari penelitian ini adalah sebagai berikut: (1) Investor muda Jawa Barat akan tetap melakukan investasi walaupun telah melakukan kesalahan keputusan investasi di masa lalu; (2) Investor muda Jawa Barat bukan di risk seeker karena rendahnya nilai di indicator tersebut; (3) Investor muda Jawa Barat jarang melakukan update informasi seputar dunia investasi; (4) Korelasi diantara variabel bebas yaitu regret aversion bias dengan risk tolerance menunjukkan korelasi yaitu sebesar 0,631 dan memiliki korelasi yang kuat dan searah antara regret aversion bias dan risk tolerance. Hal ini menunjukan bahwa regret aversion bias dapat menciptakan dan risk tolerance pada investor muda Jawa Barat; (5) Terdapat pengaruh parsial dari regret aversion bias terhadap keputusan investasi pada investor muda Jawa Barat dengan total pengaruh sebesar 0,07 atau 7\%. Hal ini menunjukan bahwa regret aversion bias berkontribusi atau berpengaruh terhadap keputusan investasi pada investor muda Jawa Barat; (6) Terdapat pengaruh parsial risk tolerance terhadap terhadap keputusan investasi pada investor muda Jawa Barat dengan total pengaruh sebesar 0,228 atau $22,8 \%$. Hal ini menunjukan bahwa risk tolerance berkontribusi atau berpengaruh terhadap keputusan investasi pada investor muda Jawa Barat; (7) Terdapat pengaruh simultan dari regret aversion bias dan risk tolerance terhadap keputusan investasi pada investor muda Jawa Barat dengan sebesar 0,298 atau $29,8 \%$, sedangkan sisanya sebesar $70,2 \%$ dipengaruhi oleh faktor lain yang tidak diteliti dalam penelitian ini. Hal ini menunjukan bahwa regret aversion bias dan risk tolerance bersama-sama memiliki pengaruh terhadap keputusan investasi investor muda Jawa Barat.

\section{DAFTAR PUSTAKA}

Pompian, Michael, M. 2006. Behavioral Finance and Wealth Management. New York: John Wiley \& Sons, Inc.
Shefrin, Hersh. 2005. A Behavioral Approach for Asset Pricing. Elseiver: Academic Press.

Bailey, Jeffrey J. \& Kinerson, Chris. 2005. Regret Avoidance and Risk Tolerance. Jurnal. Association for Financial Counseling and Planning, Vol 16 (1) Hal 23-28.

Bell, David E. 1982. Regret in Decision Making Under Uncertainty. Jurnal. Operations Reserachs, Vol. 30 Issue 5 Page 961-981.

Budiarto, Angga \& Susanti. 2017. Pengaruh Financial Literacy, Overconfidence, Regret Aversion Bias, dan Risk Tolerance Terhadap Keputusan Investasi (Studi pada investor PT. Sucorinvest Central Gani Galeri Investasi BEI Universitas Negeri Surabaya). Jurnal Ilmu Manajemen, Volume 05 Nomor 02Jurusan Manajemen Fakultas Ekonomi Universitas Negeri Surabaya.

Droms, W G. 1987. Investment asset allocation for PFP client. Journal of Accountancy, vol 163, 1987: 114-118.

Kahneman, D., \& Tversky, A. 1979. Prospect Theory: An Analysis of Decision Under Risk. Jurnal. Econometrica. vol. 47. March. no. 2 .

Loomes, Graham \& Robert Sudgen. 1982. "Regret Theory: An Alternative Theory of Rational Choice under Undercertainty". The Economic Journal, vol. 92, pp. 805-824.

Markowitz, Harry. 1952. Portfolio Selection. The Journal of Finance, vol. 7, No. 1. (Mar., 1952), pp. 77-91.

Olsen, Robert A. 1998. Behavioral Finance and Its Implications for Stock-Price Volatility. Financial Analysts Journapyl, vol. 54, No. 2, pp. 10-18.

Putra, I Putu Santika, et al. 2016. Pengaruh Literasi Keuangan, Experienced Regret, dan Risk Tolerance Pada Pemilihan Jenis Investasi. Journal of Business and Banking, vol. 5 Number 2 November 2015-April 2016 pp. 271282.

Wulandari, Dewi Ayu \& Iramani, Rr. 2014. Studi Experienced Regret, Risk Tolerance, Overconfidance dan Risk Per- 
ception Pada Pengambilan Keputusan Investasi Dosen Ekonomi. Journal of Business and Banking, vol. 4, No. 1, May 2014 Pages 55-66.

Wong, Kin Fai Ellick \& Kwong, Jessica Y.Y. 2007. The Role of Anticipated Regret in Escalation of Commitment. Journal of Applied Psychology, vol. 92, No. 2, 545-554.

Yohnson. 2008. Regret Aversion dan Risk Tolerance Investor Muda Jakarta dan Surabaya. Jurnal Manajemen dan Kewirausahaan, vol. 10 No. 2, September 2008: 163-168.

Kresna Securities. (2017). Change Name of PT Kresna Securities. Diakses 15 Febr u a r i 2018 . h t t p : / / www.kresnasecurities.com/kresna2/en/ news-report/news-room/change-nameof-pt-kresna-securitie.

Malau, Ita LismawatI f. 2018. Orang Indonesia Itu Lebih Senang Investasi Apa ya?. Diakses 27 Maret 2019. https:// www.idntimes.com/business/ economy/ita-malau/orang-indonesiaitu-lebih-senang-investasi-apa-ya/full. 